\title{
Mariangela Mazzocchi Doglio, Poesia e realtà nella scrittura drammaturgica di Henri Céard
}

\section{Mario Richter}

\section{(2) OpenEdition}

1 Journals

\section{Edizione digitale}

URL: https://journals.openedition.org/studifrancesi/26736

DOI: 10.4000/studifrancesi.26736

ISSN: 2421-5856

\section{Editore}

Rosenberg \& Sellier

\section{Edizione cartacea}

Data di pubblicazione: 1 avril 2007

Paginazione: 209

ISSN: 0039-2944

\section{Notizia bibliografica digitale}

Mario Richter, «Mariangela Mazzocchi Doglio, Poesia e realtà nella scrittura drammaturgica di Henri Céard», Studi Francesi [Online], 151 (LI | I) | 2007, online dal 30 novembre 2015, consultato il 23 novembre 2021. URL: http://journals.openedition.org/studifrancesi/26736 ; DOI: https://doi.org/ 10.4000/studifrancesi.26736

Questo documento è stato generato automaticamente il 23 novembre 2021.

\section{(c) $(1) \odot$}

Studi Francesi è distribuita con Licenza Creative Commons Attribuzione - Non commerciale - Non opere derivate 4.0 Internazionale. 


\title{
Mariangela Mazzocchi Doglio, Poesia e realtà nella scrittura drammaturgica di Henri Céard
}

\author{
Mario Richter
}

\section{NOTIZIA}

MARIANGELA MAZZOCCHI DOGLIO, Poesia e realtà nella scrittura drammaturgica di Henri Céard, in “L’analisi linguistica e letteraria", 13 (2005), pp. 159-169.

1 L'esame delle due pièces di Henri Céard, Pierrot spadassin (rappresentata a Parigi il 29 giugno 1877, certamente la stessa che fu pubblicata nel 1990 da Jean de Palacio col titolo L'Héroïque imposture, comédie fantaisiste en un acte et en vers) e Les Résignés (in tre atti e in prosa, rappresentata a Parigi il 31 gennaio 1889), porta M. Mazzocchi Doglio a concludere che «Céard dal sinistramente clownesco personaggio di Pierrot forma onirica conturbante e problematica senza felicità e senza illusioni cui solo la poesia può dare voce passa ai personaggi viventi ma braccati nel salotto del borghese inferno familiare lasciando ad ogni spettatore il compito di riflettere sulle valenze profonde di un'esistenza infelice sempre presente e sempre futuribile cui nessuno può sfuggire». 